nę postawy kanclerza, często należycie nie udowadniając swoich racji. Ponadto autorka wielokrotne stawia szereg pytań, które w ramach omawianej pracy nie zawsze znajdują odpowiedzi. Natomiast ich forma narzuca czytelnikowi negatywny stosunek wobec działalności Zamoyskiego. Pieńkowska, atakując kanclerza, bardzo często pomija milczeniem działalność Zborowskich, których polityczną postawę podczas elekcji również cechowała prywata i chęć korzystnego dla siebie rozstrzygnięcia porachunków z Zamoyskim.

Podsumowując, recenzowana książka stanowi ważne osiągnięcie badawcze, przede wszystkim dlatego, że znacznie poszerza naszą wiedzę na temat III bezkrólewia. Ukazuje główne przyczyny rozdwojonej elekcji, których genezę słusznie autorka widzi w polityce ostatnich lat panowania Stefana Batorego. Elementem pracy, który szczególnie zasługuje na wyróżnienie jest dokładne omówienie działalności prymasa Stanisława Karnkowskiego oraz senatorów koronnych niezwiązanych ze stronnictwami kanclerza i Zborowskich. Jednak niektóre sądy zawarte w monografii, szczególnie te dotyczące Jana Zamoyskiego bądź czołowych senatorów litewskich, nie zawsze znajdują wystarczające potwierdzenie w źródłach.

Piotr Łabędź (Toruń)

\title{
Anna Markiewicz, Podróże edukacyjne w czasach Jana III Sobies- kiego. Peregrinationes Jablonovianae, Wydawnictwo DiG, Warszawa 2011, ss. 370
}

$\mathrm{P}$ odróże edukacyjne - obok rewolucji druku i odkryć geograficznych - stanowily jedno z najbardziej znamiennych zjawisk społeczno-kulturowych w epoce nowożytnej. Od XVI wieku horyzonty szlacheckiej wyobraźni zaczęly się poszerzać. Ciekawość świata wzmagała ruchliwość mieszkańców Rzeczpospolitej Obojga Narodów. Mobilność ówczesnego społeczeństwa nie pozostawała bez wpływu na kształt obywatelskiego wychowania; w wieku XVII zagraniczna podróż wchodzi na stałe do kanonów pedagogicznych. Jednak jeśli peregrynacja w obce kraje stanowiła jeden z możliwych elementów kształcenia szlachcica czy zamożnego mieszczanina, dla magnata stawała się warunkiem sine qua non młodzieńczej edukacji. Była jednocześnie ostatnim stopniem kształcenia, jego zwieńczeniem, 
a także przygotowaniem do pełnienia służby publicznej i wejściem w dorosłe życie. Jej uczestnik był wyposażany w instrukcje podróżnicze, które oprócz wielu rad i napomnień nakazywały młodemu peregrynantowi sporządzanie dziennika podróży, który przypominał będzie o widzianych miejscach i ludziach.

Problematyka ta przez ostatnie lata doczekała się wielu opracowań. Prace Antoniego Mączaka czy Hanny Dziechcińskiej zawierają wiele cennych informacji na temat turystyki staropolskiej, jej wszelkich odmian, a także związanej z nią twórczości piśmiennej, którą stanowiły dzienniki, itineraria, pamiętniki czy diariusze podróży. Do badań tych nawiązuje wydana w 2011 r. nakładem warszawskiego wydawnictwa DiG książka Anny Markiewicz Podróże edukacyjne w czasach Jana III Sobieskiego. Monografia zawiera podtytuł: Peregrinationes Jablonovianae, co sugeruje czytelnikowi, że zasadniczym tematem książki będą tury kawalerskie odbyte przez członków rodu Jabłonowskich herbu Prus III, a konkretnie synów hetmana wielkiego koronnego Stanisława Jana. Jak sama autorka pisze: „zagadnienia poruszone w pracy zostały wprawdzie osnute wokół grand tour członków rodziny Jabłonowskich oraz ich krewnych, ale stały się jednocześnie punktem wyjścia do szerszych rozważań ukazujących na rozleglejszym tle podróże z czasów panowania Jana III Sobieskiego, będące panoramą wielu typów podróży oraz podróżników kierowanych najróżniejszymi motywacjami” (s. 17). Tematyka pracy wpisuje się w krąg zainteresowań ${ }^{1}$ badaczki, który oscyluje wokół zagadnień związanych z problematyką staropolskiej mentalności, komunikacji społecznej i tur kawalerskich w XVII w.

Podróże edukacyjne mają układ problemowo-chronologiczny. Składają się z czterech rozdziałów, wstępu, zakończenia oraz itinerarium podróży braci Jabłonowskich. Całość uzupełnia bibliografia oraz indeksy: osobowy i geograficzny. Sporym ułatwieniem dla czytelnika jest pięć map z trasami podróży Teodora Billewicza, Jana Stanisława i Aleksandra Jabłonowskich, Karola Stanisława Jabłonowskiego i Jerzego Józefa Radziwiłła, Adama Mikołaja Sieniawskiego oraz Janusza Antoniego i Michała Serwacego Wiśniowieckich. Plany te pozwalają w szybki sposób zorientować się w przebiegu tury kawalerskiej poszczególnych magnatów i uwidaczniają rozróżnienie na le grand i le petit tour.

Pracę można podzielić na dwie części. Pierwsza dotyczy ogólnych rozważań na temat uczonych peregrynacji polskiej szlachty, druga, będąca zasadniczą częścią rozprawy, przynosi szczegółowy opis grand tour braci Jabłonowskich z lat 80. i 90.

${ }^{1}$ Por.: Listy Andrzeja Potockiego do odbywającego podróż edukacyjna Adama Mikołaja Sieniawskiego z lat 1685-1686, „Rocznik Biblioteki Naukowej PAU i PAN w Krakowie” 52 (2007); "Miasto wszystkich delicyi petne”. Paryż $w$ relacjach polskich podróżników z lat osiemdziesiatych XVII wieku, [w:] Sztuka i podróżowanie. Studia teoretyczne i historyczno-artystyczne, red. P. Krasny i D. Ziarkowski, Kraków 2009. 
XVII w. napisany w oparciu o sporządzone przez młodych magnatów i ich guwernerów diariusze podróży.

W rozdziale pierwszym autorka skupia się na rozwoju tradycji podróżniczych w epoce staropolskiej. Polacy, mimo obawy przed nieznanym, chętnie opuszczali granice Rzeczpospolitej. Wyprawom tym towarzyszyły różne motywacje: udawano się zagranicę z misją dyplomatyczną, $\mathrm{w}$ celu podratowania słabego zdrowia czy w końcu dla zdobycia wykształcenia. Od czasów średniowiecza do XVIII wieku uczone podróże szlachty przeszły swoistą ewolucję. Podejmowane dla zdobycia wiedzy na zachodnich uniwersytetach peregrinatio academica przeobraziło się $\mathrm{w}$ mniej związaną z edukacją grand tour (Kavalierstour, Kavaliersreise) odbywaną przez członków bogatych, magnackich rodzin. Siedemnastowieczny peregrynant miał zapoznać się z najważniejszymi miejscami na europejskiej mapie, zdobyć niezbędne doświadczenie, ogładę, a także poznać interesujących ludzi. Stąd też głównymi kierunkami podróży stawał się Paryż i Rzym. Obecność w stolicy Francji nieodłącznie związana była z wizytą na dworze Ludwika XIV i podziwianiem Wersalu. Do położonego nad Tybrem wiecznego miasta udawano się obejrzeć pozostałości antycznego świata, mając nadzieję uzyskania audiencji u papieża. Obok typologii i motywacji staropolskiego podróżnictwa rozdział ten traktuje o przeciwnościach, z którymi borykali się podróżnicy, przebywając z jednego miasta do drugiego. $\mathrm{Na}$ nie składały się przeprawy przez górskie pasma i morza, niesprzyjające warunki pogodowe, rozboje i wojny.

Następną część pracy stanowią rozważania nad guwernerami młodych peregrynantów. Dla magnata posyłającego syna w zagraniczną podróż wybór odpowiedniego opiekuna stawał się istotną kwestią z wychowawczego, organizacyjnego i finansowego punktu widzenia. W końcu wychowanie przyszłego światłego obywatela w dużej mierze zależało od jego nauczyciela, a nie zawsze przynależność guwernera do stanu zakonnego (zazwyczaj do Societas Iesu) gwarantowała wysokie standardy pedagogiczne i udany wojaż. Pod koniec XVII w. habit w wielu miejscach Europy kojarzył się z anachronizmem i jego towarzystwo narażało młodych peregrynantów na kpinę. Stąd też poszukiwanie kandydata na przyszłego gubernatora było istotnym elementem planowania podróży zagranicznej. Po jego ustaleniu należało zawrzeć precyzyjną umowę, a także ustalić kompetencje (pilnowanie finansów, prowadzenie korespondencji a także szereg codziennych, prozaicznych zajęć) należące do opiekunów podróży. Te kwestie zostają omówione na przykładzie konkretnych guwernerów: Jana Michała Kossowicza, Szymona Gutowskiego (opiekunowie Jabłonowskich), Wojciecha Romualda Foxa i Jerzego Kazimierza Woynarowskiego.

Trzeci rozdział, będący zasadniczym i najobszerniejszym elementem recenzowanej pracy, to grand tour Jana Stanisława i Aleksandra Jana Jabłonowskich z lat 
1782-86, a więc próba scharakteryzowania tur kawalerskich w latach 80. XVII w. Podróż młodych magnatów zrekonstruowana jest na podstawie dwóch zachowanych źródeł: Peregrynacji do cudzych krajów Jaśnie Wielmożnych Ich Mciów Panów Jana i Aleksandra Jabtonowskich wojewodziców ziem ruskich pióra ich guwernera, Jana Kossowicza, a także Diarium mansionis Parisiis et diarium itineris in Angliam conscriptum ab Alexandro in Jabtonow Jabtonowski. Autorka, dodatkowo korzystając z korespondencji młodych szlachciców, przedstawia przebieg ich tury kawalerskiej. Celem podróży - jak wielu pozostałych odbywanych przez szlachtę polską - jest z jednej strony edukacja, $\mathrm{z}$ drugiej dłuższy pobyt w ówczesnym centrum kulturalnym i politycznym - Paryżu. Obecność Jabłonowskich w stolicy Francji wypełnia znaczną część tego rozdziału. Miasto nad Sekwaną stanowi stałe miejsce pobytu peregrynantów, z niego udają się w podróże do Anglii, Hiszpanii czy Włoch i za chwilę wracają z powrotem. W Paryżu, oprócz wizyt w Wersalu, zwiedzania dworu Ludwika XIV i spotkań z Królem Słońce, odbywają edukację w College Louis-le-Grand. Czytelnik ma możliwość zapoznania się z obrazem codziennego życia w kolegium jak i samym Paryżu. Czas wolny wypełniony jest dodatkowymi zajęciami edukacyjnymi z szermierki czy nauki tańca, zwiedzaniem zabytków, w szczególności budowli sakralnych, i podtrzymywaniem kontaktów towarzyskich. Wedle autorki relacje z przebywającymi nad Sekwaną obywatelami Rzeczpospolitej Obojga Narodów miały specjalne znaczenie dla podróżników. Badaczka poświęca im wiele miejsca, a nawet niepotrzebnie powtarza podobne treści w dwóch podrozdziałach (Spotkania z Polakami i Codzienne życie w Paryżu). Aby zawarty w tej części pracy opis podróży edukacyjnych lat 80 . XVII wieku był pełniejszy, czytelnik otrzymuje grand tour Adama Mikołaja Sieniawskiego. Omawiając turę kawalerską przyszłego hetmana wielkiego koronnego, Anna Markiewicz nie dysponuje zachowanym źródłem bezpośrednim, wobec czego musi korzystać z fragmentarycznych informacji zawartych w diariuszu Jabłonowskich, korespondencji guwernerów Sieniawskiego oraz stawiać wiele hipotez.

Ostatni rozdział poświęcony jest podróżom zagranicznym odbywanym w latach 90. XVII stulecia. Ta część książki, o wiele krótsza od poprzedniej, pokazuje następną grupę podróżników - młodsze rodzeństwo, dalszych członków rodziny, klientów niegdysiejszych peregrynantów. Podróż najmłodszego z braci Jabłonowskich, Stanisława Karola, ma udowodnić, że kolejne grupy podróżnych podążały tymi samymi szlakami i docierały do sprawdzonych miejsc. Jak sama badaczka stwierdza: „Bez trudu można wykazać, że najmłodszy - wówczas piętnastoletni - syn hetmana poszedł w ślady starszych braci i po przybyciu do Paryża rozpoczął edukację w słynnym paryskim kolegium jezuitów” (s. 230). Istotą tej części pracy jest teza o ciągłości i wykształceniu się tradycji uczonych podróży. 
Przechodząc do wniosków, należy stwierdzić, że pewne zastrzeżenia budzi rozdzielenie podróży edukacyjnych za Jana III Sobieskiego na lata 80. i 90. Podział ten wydaje się niepotrzebny, gdyż nie widać zasadniczych różnic między uczonymi peregrynacjami na przestrzeni tych dwóch dekad. A teza dowodząca o ciągłości tradycji, przekazywaniu sposobu podróży kolejnej grupie wędrowców wydaje się niewystarczająca. Zgodzić się można z końcową cezurą. Nowy porządek polityczny w Europie, wynikający z wojny północnej i objęcia tronu polskiego przez przedstawiciela dynastii saskiej, zmieniał plany europejskiej peregrynacji.

Hanna Dziechcińska zauważa, że w dziennikach staropolskich można wskazać trzy zasadnicze elementy, które tworzyły przedmiot relacji z nieznanych krajów: przyrodę, miasto, ludzi². A. Markiewicz sporo miejsca poświęca napotykanym przez peregrynantów na europejskich szlakach rodaków i kontaktom utrzymywanych z nimi. Tak obszerne omówienie jest uzasadnione, ponieważ znajomości zawarte w europejskich podróżach miały dla młodego magnata kluczowe znaczenie w przyszłej krajowej karierze.

$\mathrm{Na}$ uwagę zasługuje obszerna kwerenda źródłowa i imponująca analiza literatury przedmiotu. Szczególnie cenna jest charakterystyka kilku nieuznanych dotychczas sylwetek guwernerów. Zagadnienie te jak do tej pory nie było szerzej omawiane.

Książka Anny Markiewicz ma dużą wartość poznawczą. Autorce udało się przedstawić wybraną grupę reprezentantów odbywającą podróż edukacyjną, omówić etapy ich grand tour. Ponadto Podróże edukacyjne ukazują jaki wpływ miała zagraniczna peregrynacja dla młodej magnaterii, która za rządów Augusta II będzie odgrywała wiodącą rolę w Rzeczpospolitej Obojga Narodów.

Łukasz Wróbel (Toruń)

${ }^{2}$ H. Dziechcińska, O staropolskich dziennikach podróży, Warszawa 1991, s. 26. 